\title{
CHOLANGIOSCOPY IN BILE DUCT DISEASE: a case series
}

\author{
Eduardo Guimarães Hourneaux de MOURA, Tomazo FRANZINI, Renata Nobre MOURA, \\ Fred Olavo Aragão Andrade CARNEIRO, Everson Luiz de Almeida ARTIFON and Paulo SAKAI
}

\begin{abstract}
Context - Direct endoscopic visualization of biliopancreatic duct is certainly one of the greatest advances of therapeutic endoscopy. The use of a single-operator cholangioscopy platform (SpyGlass) is a promising technique in the evaluation of diseases such as indeterminate biliary stricture and giant choledocholitiasis. This is the first Brazilian case series using this technology. Methods - We report a case series of 20 patients in whom SpyGlass was used with diagnostic and therapeutic intention. Results Most patients were female (60\%) and the median age was 48 years (ranging from 14 to 94 ). Choledocholitiasis was the most common indication (12/20), and electrohydraulic lithotripsy was applied in eight (66\%). Electrohydraulic lithotripsy was successful in seven $(87.5 \%)$ patients. Partial stone fragmentation occurred in one patient with large stone causing stone-choledochal disproportion, which was conducted with biliary plastic stent placement and a second scheduled endoscopic approach in 3 months. In cases of undefined etiology of biliary strictures, it was possible to exclude malignancy due to direct visualization (7/8) or biopsy (1/8). One complication occurred (duodenal perforation) after papillary balloon dilation. Conclusion - The use of SpyGlass demonstrated the benefits, especially in cases of large bile duct stones and indeterminate biliary strictures. Other potencial improvements such as reduction on radiation exposure should be confirmed in prospective studies.
\end{abstract}

HEADINGS - Cholangiography, utilization. Lithotripsy. Choledocholithiasis. Gallstones.

\section{INTRODUCTION}

In the last decades, endoscopic retrograde cholangiopancreatography (ERCP) has improved on diagnosis and treatment of biliary diseases, with over $90 \%$ success rates ${ }^{(7,16,17)}$. However, despite ERCP being considered the gold standard for diagnosis of common bile duct (CBD) stones, there is $8 \%-16 \%$ of false negative cholangiography ${ }^{(16)}$. Some conditions such as large bile duct stones $(>15 \mathrm{~mm})$ and biliary strictures of undetermined cause remain challenging. Even with technological advances in imaging methods, differential diagnosis between benign and malignant biliary strictures may remain unclear in $50 \%$ of the cases ${ }^{(7,12)}$.

In this scenario, "mother-baby scope" cholangioscopy was introduced in 1975 The aim was to overcome diagnostic limitations of biliary diseases, allowing direct visualization of bile ducts ${ }^{(7,12)}$. Although available for more than three decades, its use remained restrict mostly due to high cost method, and the need of two experienced endoscopists during the same procedure $^{(1,2,11,12)}$.

In 2006, a new single-operator cholangioscopy platform (SpyGlass) was developed (Figure 1). It allowed direct view biopsies and lithotripsy to become a more effective and feasible procedures ${ }^{(7)}$. As a consequence of its numerous advantages, the use of
SpyGlass became widespread, currently being used by over 800 endoscopists worldwide with more than 35000 procedures performed ${ }^{(16)}$.

The combination between SpyGlass and electrohydraulic lithotripsy (EHL), which was usually used by urologists, allowed treatment of choledocholitiasis through specific biliary catheters by stone fragmentation under direct view and subsequent fragments removal.

In a study published by Chen et al. ${ }^{(2)}$, success rate of cholangioscopy feasibility with SpyGlass was $89 \%$. Other studies demonstrate a rate of success up to $97 \%$, and in cases of undefined etiology biliary stricture important information were added ${ }^{(1,2,11,12,13)}$.

\section{METHODS}

This is a prospective study of 20 consecutive and not randomized patients. Inclusion criteria were undefined bile duct strictures and large CBD stones that were difficult to be removed by ERCP (Figure 2).

All procedures were performed by two experienced endoscopists (EGHM and TF), using a therapeutic duodenoscope (ED-250XT5; Fujinon). Forceps biopsies (Spybite) of the specimens were taken under direct visualization. A force generator Nortech autolith ${ }^{\circledR}$ (Northgate Technologies, Inc, Elgin, Ill) and a $1.9 \mathrm{~F}$

Declared conflict of interest of all authors: none

Departamento de Gastroenterologia, Serviço de Endoscopia Gastrointestinal, Universidade de São Paulo - USP, SP, Brasil

Correspondence: Tomazo Franzini. Rua Dr. Enéas de Carvalho Aguiar, 255. Cerqueira César. São Paulo- SP. 05403-000. E-mail: tomazof@uol.com.br 


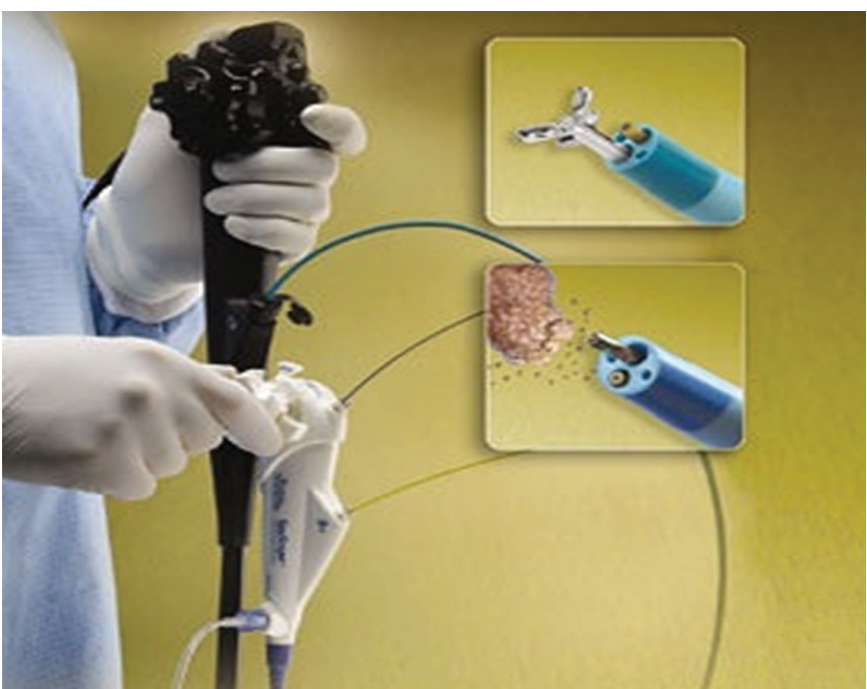

FIGURE 1. Spyglass ${ }^{\mathrm{TM}}$. Single operator cholangioscopy plataform

probe lithotriptor device were used in patients undergoing electrohydraulic lithotripsy, with an initial setting of 5 pulses per second and $50 \mathrm{~W}$ of power and, if necessary, gradually increases up to 10 pulses per second and $100 \mathrm{~W}$ of power.

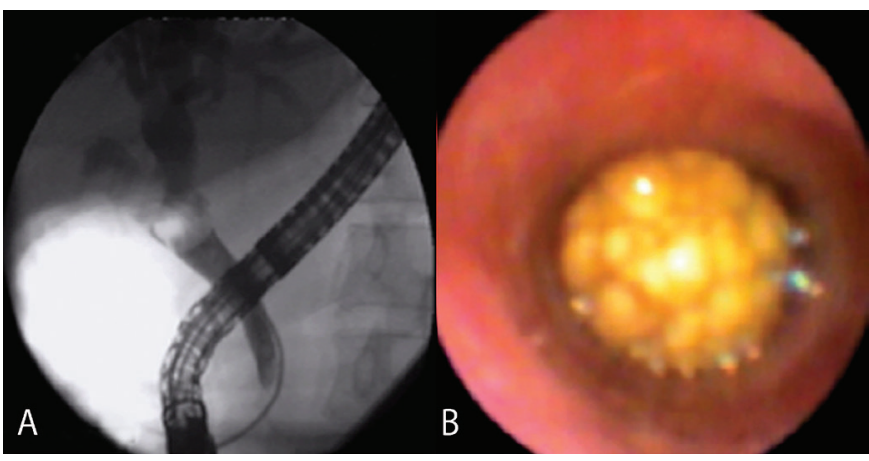

FIGURE 2. Giant bile duct stone. A: Radiologic view; B: Direct view

Success rate of EHL procedure was considered when a large stone was fragmented and removed from CBD.

Antibiotic, Ciprofloxacin $400 \mathrm{mg}$ IV, was given as prophylaxis. The procedure was performed under conscious sedation using a combination of fentanyl, midazolam and propofol.

Patients were submitted to conventional ERCP with CBD cannulation using a guidewire. Cholangiography was obtained after contrast media injection. Sphincterotomy was performed in all cases, nine of these in the same procedure and eleven had it previously done (Figure 3). Seven patients

\begin{tabular}{|c|c|c|c|c|c|}
\hline Patient & Age & Sex & Indication & ERCP procedures & SpyGlass findings/procedures \\
\hline 1 & 14 & $\mathrm{~F}$ & Choledocholitiasis & Sphincterotomy + Papillary balloon dilation $(12 \mathrm{~mm})$ & Electrohydraulic lithotripsy \\
\hline 2 & 56 & $\mathrm{~F}$ & Biliary stricture & Biliary plastic stent $(10 \mathrm{~F}$ x $10 \mathrm{~cm})$ & Stricture direct analysis with no bile duct injury \\
\hline 3 & 58 & M & Choledocholitiasis & Sphincterotomy + Biliary plastic stent $(10 \mathrm{~F} \times 12 \mathrm{~cm})$ & Electrohydraulic lithotripsy \\
\hline 4 & 56 & $\mathrm{~F}$ & $\begin{array}{l}\text { Biliary stricture suspicion } \\
\text { with biliary tree dilation }\end{array}$ & Extractor balloon biliary sweeping & Stricture direct analysis with no bile duct injury \\
\hline 5 & 59 & $\mathrm{~F}$ & Choledocholitiasis & Sphincterotomy + Extractor balloon biliary sweeping & Electrohydraulic lithotripsy \\
\hline 6 & 56 & $\mathrm{~F}$ & $\begin{array}{l}\text { Choledocholitiasis after } \\
\text { biliodigestive bypass }\end{array}$ & & Anastomosis direct analysis \\
\hline 7 & 52 & $\mathrm{M}$ & Biliary stricture & $\begin{array}{l}2 \text { Biliary plastic stents } \\
(8.5 \mathrm{~F} \times 9 \mathrm{~cm} \text { and } 10 \mathrm{~F} \times 9 \mathrm{~cm})\end{array}$ & Fibrosis \\
\hline 8 & 80 & $\mathrm{~F}$ & Choledocholitiasis & Extractor balloon biliary sweeping & Electrohydraulic lithotripsy \\
\hline 9 & 82 & $\mathrm{M}$ & Biliary stricture & Sphincterotomy + Papillary balloon dilation $(10 \mathrm{~mm})$ & Fibrosis and CBD stones \\
\hline 10 & 68 & M & Biliary stricture & $\begin{array}{l}\text { Sphincterotomy + Papillary balloon dilation }(10 \mathrm{~mm})+ \\
\text { Biliary plastic stent }(8.5 \mathrm{~F} \text { x } 12 \mathrm{~cm})\end{array}$ & $\begin{array}{l}\text { Anastomosis annular stricture associated with } \\
\text { biliary stasis, sludge and stones in proximal bile } \\
\text { duct }\end{array}$ \\
\hline 11 & 60 & $\mathrm{~F}$ & Biliary stricture & & Hiperplasia area \\
\hline 12 & 23 & $\mathrm{~F}$ & Choledocholitiasis & Extractor balloon biliary sweeping & Choledochal direct analysis \\
\hline 13 & 54 & $\mathrm{M}$ & Choledocholitiasis & Sphincterotomy + Papillary balloon dilation $(13.5 \mathrm{~mm})$ & Guidewire upstream to biliary left tree \\
\hline 14 & 57 & $\mathrm{~F}$ & Biliary stricture & Biliary plastic stent $(7 \mathrm{~F} \times 9 \mathrm{~cm})$ & Irregular and friable mucosa. Biopsy with spybite \\
\hline 15 & 49 & $\mathrm{~F}$ & Choledocholitiasis & Papillary balloon dilation $(12 \mathrm{~mm})$ & \\
\hline 16 & 94 & M & Choledocholitiasis & $\begin{array}{l}\text { Sphincterotomy + Papillary balloon dilation }(15 \mathrm{~mm})+ \\
\text { Biliary plastic stent }(7 \mathrm{~F} \times 9 \mathrm{~cm})\end{array}$ & Electrohydraulic lithotripsy \\
\hline 17 & 74 & $\mathrm{M}$ & Biliary stricture & Basket biliary sweeping & Fibrosis and CBD stones \\
\hline 18 & 45 & $\mathrm{~F}$ & Choledocholitiasis & Sphincterotomy + Papillary balloon dilation $(10 \mathrm{~mm})$ & Electrohydraulic lithotripsy \\
\hline 19 & 63 & $\mathrm{~F}$ & Choledocholitiasis & Sphincterotomy + Papillary balloon dilation $(12 \mathrm{~mm})$ & Electrohydraulic lithotripsy \\
\hline 20 & 64 & M & Choledocholitiasis & $\begin{array}{l}\text { Papillary balloon dilation }(15 \mathrm{~mm}) \\
\text { Biliary plastic stent }(10 \mathrm{~F} \times 12 \mathrm{~cm})\end{array}$ & Electrohydraulic lithotripsy \\
\hline
\end{tabular}

FIGURE 3. Patient's demographic, SpyGlass indications, ERCP and SpyGlass procedures

Sex F: female; Sex M: male 
underwent balloon dilation of the major papilla, ranging from 10 to $15 \mathrm{~mm}$, according to stone size and distal bile duct diameter. After this analysis, cholangioscopy was performed and the specific treatment was instituted for each case.

In cases of giant CBD stones (Figure 2), it was created a liquid interface by flushing a $0.9 \%$ saline solution through an irrigating pump connected to SpyGlass system. After stone fragmentation with electrohydraulic shock waves, its removal was made using conventional methods such as extractor balloon or basket (Boston Scientific).

\section{RESULTS}

From August to November 2013, 20 patients were consecutively included in this study. Eight $(40 \%)$ were male and $12(60 \%)$ female. The ages ranged from 14 to 94 years with mean and median of 58 and 48 years, respectively. Patient's demographic, SpyGlass indications, ERCP and SpyGlass procedures are presented in Figure 3.

Main ERCP indication was choledocolitiasis (12) with stones ranging from 10 to $35 \mathrm{~mm}$. EHL was performed in eight cases, with a success rate of $87.5 \%$ (seven cases) on fragmentation and stone removal (Figure 4). Failure occurred in one patient, despite successful lithotripsy therapy, stone removal was incomplete due to a disparity between the fragments of the stone post EHL and distal choledochal portion. CBD stenting was provided. In two cases, multiple giant stones were identified, and the distal ones were successfully treated with EHL followed by basket extraction. In order to avoid complications of a prolonged procedure plastic stent was placed and a second Spyglass cholangioscopy with EHL scheduled in 3 months. (Table 1)

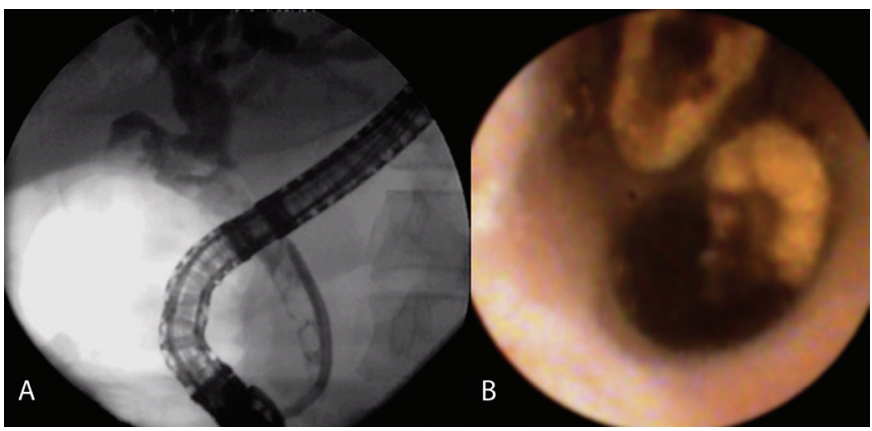

FIGURE 4. Fragmented stone post EHL. A: Radiologic view; B: Direct view

Biliary stricture was evaluated in eight patients. Malignancy was excluded in seven cases after cholangioscopy due to absence of protruding or friable lesions (Table 1). Only one patient presented an area of irregular and friable mucosa at the medial portion of the common bile duct, which was biopsied with Spybite and the histopathological evaluation did not evidenced malignancy.

In a patient with stricture of CBD anastomosis after orthotopic liver transplantation, it was possible to identify an annular stricture associated with biliary stasis, sludge and stones in proximal bile ducts. Balloon dilation of the stricture was performed, followed by SpyGlass electrohydraulic lithotripsy and successful clearance of the stone fragments.

In one case, it was not possible to advance the cholangioscopy equipment due to the scar stricture in the distal CBD. Papillary balloon dilation $(10 \mathrm{~mm})$ was required, but occurred a duodenal perforation. The patient was treated with clinical management and antibiotic therapy, but followed by cardiac complications and died 48 hours after the procedure.

There were no cases of cholangitis or other complications in this study.

\section{DISCUSSION}

The pioneering use of cholangioscopy in our Brazilian study with SpyGlass significantly expanded the diagnostic and therapeutic possibilities of biliary diseases, especially in cases of difficult management with conventional methods, either endoscopic or radiologic. However, applications of this method are still limited to large centers, as a result of its high cost and technical difficulties ${ }^{(5)}$.

SpyGlass cholangioscopy main benefits are evaluation of strictures and treatment of large CBD stones, in which electrohydraulic lithotripsy is the major therapeutic application. Thereby in our case series, therapeutic success of EHL was achieved in $87.5 \%(7 / 8)$ of the patients, which is similar to current literature that reports success rates ranging from $85 \%$ to $97 \%(3,4,10,12)$.

Peroral cholangioscopy provides direct visual evaluation of the bile duct, thus allowing guided tissue sampling ${ }^{(5,8)}$. The addition of cholangioscopy findings increased diagnostic accuracy of malignant bile duct strictures to more than $90 \%{ }^{(6,14)}$. In a study of Siddiqui et al. ${ }^{(15)}$, SpyGlass system had $77 \%$ accuracy in diagnosis of malignancies that were inconclusive on the basis of ERCP-guided brush or EUS fine-needle aspiration analyses. In this case series, SpyGlass evaluation for biliary strictures of undetermined cause were performed in 8 patients; however there was only

TABLE 1. Choledocholitiasis analysis and performed procedures with SpyGlass

\begin{tabular}{lc}
\hline Size mean (range) & $17.8(10-35) \mathrm{mm}$ \\
\hline Estimated size & 4 \\
$<15 \mathrm{~mm}$ & 7 \\
$\geq 15 \mathrm{~mm}$ & 1 \\
No stone found & \\
Location & 9 \\
Common bile duct & 1 \\
Common hepatic duct & 1 \\
Intrahepatic duct & 8 \\
Stone treated with EHL & 7 \\
Success & 1 \\
Failured (Stone-choledochal disproportion) & \\
\hline
\end{tabular}


one case with suspected bile duct lesion on cholangioscopy. This lesion was biopsied under direct view, and anatomopathological analysis resulted negative for malignancy despite appropriate tissue sampling. In the other seven cases, cholangioscopy was able to avoid further procedures, once no endoscopic findings of malignancy on bile duct were identified. Based on this, the supposition that ERCP findings of undeterminated biliary stricture should lead to cholangioscopic evaluation is valid. However, our results may not be conclusive once our case number was restricted to eight non-prospective patients.

Since its creation, the range of cholangioscopy diagnostic and therapeutic procedures is increasing. Besides EHL therapy it has been described several others feasible procedures such as laser lithotripsy, photodynamic therapy in biliary neoplasms, endomicroscopy mucosal analysis, and assistance in the upstream of guidewire over choledochal complex strictures. Other indications are being studied, such as pancreatography, assisting in the differential diagnosis of pancreatic diseases.

The most commom complication of SpyGlass cholangioscopy is acute cholangitis, occurring in 3.1\% of cases ${ }^{(16)}$. Other complications described are: bacteremia $(0.9 \%)$, transient hypotension $(0.9 \%)$, abdominal pain and distension $(0.9 \%)$, pancreatitis $(0.4 \%)$, and hyperamylasemia $(0.4 \%)$. Bile duct perforation was reported in one $(1.5 \%)$ case. Minor hemobilia without clinical repercussions after electrohydraulic lithotripsy was observed in up to $20 \%$ of the patients ${ }^{(12)}$. In our study, there were no complications related to the SpyGlass procedure, once the duodenal perforation resulted from papillary balloon dilation.

Despite being a revolutionary technique, there are still some limitations such as high cost and small working channel diameter $(1.2 \mathrm{~mm})$, which requires the use of specific accessories. Besides this method incorporation, professional training and technique development are extremely important, as well as image qualities improvements and a guideline on exam indication criteria. Therefore, experienced endoscopists require a learning curve to handle the equipment, to perform therapeutic procedures, and to proper analyze cholangioscopic findings ${ }^{(9)}$.

This case series demonstrated that cholangioscopy with Spyglass platform is helpful in selected cases, especially those difficult to handle with conventional endoscopic techniques. In addition, we observed potential advantages such as reduction of radiation exposure due to direct visualization of the bile duct. Cholangioscopy shows up extremely promising horizons for both diagnosis and therapy in bile duct disease. The development of imaging technology and accessories should not be a very distant reality. Certainly more and more studies will be published solidifying the threshold of this new frontier by gastrointestinal endoscopy.

Moura EGH, Franzini T, Moura RN, Carneiro FOAA, Artifon ELA, Sakai P. Colangioscopia nas afecções biliares: uma série de casos. Arq Gastroenterol. 2014,51(3):250-4.

RESUMO - Contexto - A visão endoscópica direta das vias biliopancreáticas é certamente um dos maiores avanços na endoscopia terapêutica. O uso da plataforma de colangioscopia de operador-único (SpyGlass) é uma técnica promissora na avaliação de afecções tais como estenoses de etiologia indefinida e coledocolitíase gigante. Essa é a primeira série de casos brasileira utilizando o método. Métodos - Reportamos uma série de casos de 20 pacientes nos quais foi realizado Spyglass com objetivos diagnósticos e terapêuticos. Resultados - A maioria dos pacientes era do sexo feminino (60\%), com idade que variou de 14 a 94 anos (mediana de 48). Coledocolitíase foi a indicação mais comum (12/20) e litotripsia eletrohidráulica foi realizada em oito $(66 \%)$. Litotripsia eletrohidráulica foi realizada com sucesso em sete $(87,5 \%)$ pacientes. Fragmentação parcial dos cálculos ocorreu em um paciente com desproporção cálculo-coledociana, sendo conduzido com colocação de prótese plástica e reabordagem endoscópica programada em 3 meses. Nos casos de estenoses biliares de etiologia indeterminada, foi possível a exclusão de malignidade devido a visualização direta (7/8) ou biópsia (1/8). Uma complicação ocorreu (perfuração duodenal) após dilatação balonada da papila. Conclusão - Foram demonstrados os benefícios do uso do Spyglass, principalmente nos casos de coledocolitíase gigante e estenoses biliares de etiologia indefinida. Outras potenciais vantagens como a redução da exposição à radiação deve ser confirmada em estudos prospectivos posteriores.

DESCRITORES - Colangiografia, utilização. Litotripsia. Coledocolitíase. Cálculos biliares. 


\section{REFERENCES}

1. Cennamo V, Luigiano C, Fabbri C, Maimone A, Bazzoli F, Ceroni L, et al. Cholangioscopy using a new type of cholangioscope for the diagnosis of biliary tract disease: a case series. Endoscopy. 2012;44:878-81.

2. Chen YK, Pleskow DK. SpyGlass single-operator peroral cholangiopancreatoscopy system for the diagnosis and therapy of bile-duct disorders: a clinical feasibility study. Gastrointestinal Endoscopy. 2007;65:832-41.

3. Chen YK, Parsi MA, Binmoeller KF, Hawes RH, Pleskow DK, Slivka A, et al. Single-operator cholangioscopy in patients requiring evaluation of bile duct disease or therapy of biliary stones. Gastrointestinal Endoscopy. 2011;74:805-14.

4. Draganov PV, Lin T, Chauhan S, Wagh MS, Hou W, Forsmark CE. Prospective evaluation of the clinical utility of ERCP-guided cholangiopancreatoscopy with a new direct visualization system. Gastrointestinal Endoscopy. 2011;73:971-9.

5. Draganov PV, Chauhan S, Wagh MS, Gupte AR, Lin T, Hou W, Forsmark CE. Diagnostic accuracy of conventional and cholangioscopy-guided sampling of indeterminate biliary lesions at the time of ERCP: a prospective, long-term follow-up study. Gastrointestinal Endoscopy. 2012;75:347-53.

6. Fukuda Y, Tsuyuguchi T, Sakai Y, Tsuchiya S, Saisyo H. Diagnostic utility of peroral cholangioscopy for various bile-duct lesions. Gastrointestinal Endoscopy. 2005;62:374-82.

7. Kahaleh M. Spyglass Direct Visualization System. Clin Endosc. 2012,45:316-8

8. Kalaitzaki E, Webster GJ, Oppong KW, Kalli Y, Vlanianos P, Huggett M, et al. Diagnostic and therapeutic utility of single-operator peroral cholangioscopy for indeterminate biliary lesions and bile duct stones. European Journal of Gastroenterology and Hepatology. 2012;24:656-64.

9. Manta R, Frazzoni M, Conigliaro R, Maccio L, Melotti G, Dabizzi E, et al. SpyGlass single-operator peroral cholangioscopy in the evaluation of indeterminate biliary lesions: a single-center, prospective, cohort study. Surg Endosc. 2013;27:1569-72.
10. Maydeo A, Kwek BEA, Bhandari S, Bapat M, Dhir V. Single-operator cholangioscopy-guided laser lithotripsy in patients with difficult biliary and pancreatic ductal stones. Gastrointestinal Endoscopy. 2011;74:1308-14.

11. Moon JH, Terheggen G, Choi HJ, Neuhaus H. Peroral Cholangioscopy: Diagnostic and Therapeutic Applications. Gastroenterology. 2013;144:276-82.

12. Nguyen NQ, Binmoeller KF, Shah JN. Cholangioscopy and pancreatoscopy. Gastrointestinal Endoscopy. 2009;70:1200-10.

13. Nishikawa T, Tsuyuguchi T, Sakai Y, Sugiyama H, Miyazaki M, Yokosuka O. Comparison of the diagnostic accuracy of peroral videocholangioscopic visual findings and cholangioscopy-guided forceps biopsy findings for indeterminate biliary lesions: a prospective study. Gastrointestinal Endoscopy. 2013;77:219-26.

14. Ramchandani M, Reddy N, Gupta R, Lakhtakia S, Tandan M, Darisetty S, et al. Role of single-operator peroral cholangioscopy in the diagnosis of indeterminate biliary lesions: a single-center, prospective study. Gastrointestinal Endoscopy. 2011;74:511-9.

15. Siddiqui AA, Mehendiratta V, Jackson W, Loren DE, Kowalshi TE, Eloubeidi MA. Identification of cholangiocarcinoma by using the Spyglass Spyscope for peroral cholangioscopy and biopsy collection. Clinical Gastroenterology and Hepatology. 2012;10:466-71.

16. Williamson JB, Draganov PV. The usefulness of SpyGlassTM choledochoscopy in the diagnosis and treatment of biliary disorders. Curr Gastroenterol Rep. 2012;14:534-41.

17. Wright H, Sharma S, Gurakar A, Sebastian A, Kohli V, Jabbour N. Management of biliary stricture guided by the Spyglass Direct Visualization System in a liver transplant recipient: an innovative approach. Gastrointestinal Endoscopy. 2008; 67:1201-2.

Received 28/1/2014 Accepted 25/3/2014 